Acta vet. scand. $1978,19,407-412$.

From the State Veterinary Serum Laboratory, Copenhagen, Denmark.

\title{
HETEROGENEITY OF MYCOPLASMA DISPAR
}

\author{
By \\ N. F. Friis
}

FRIIS, N. F.: Heterogeneity of Mycoplasma dispar. Acta vet. scand. 1978, 19, 407-412. - Seventy bovine mycoplasma strains recovered from cases of calf pneumonia, and all displaying the cultural characteristics of Mycoplasma dispar, were compared to the type strain of this species by the disc growth inhibition test, the metabolism inhibition test and indirect epi-immunofluorescence test applied to colonies on agar. Sixty-seven strains were found to be identical with $M$. dispar. The remaining three strains formed a distinct serogroup partially separate from the type strain of M. dispar, but the difference from the type strain was not considered great enough to warrant the establishment of a subspecies.

mycoplasma dispar; bovine mycoplasmas.

In Denmark, the mycoplasma flora of pneumonic calf lungs is dominated by M. dispar, M. bovirhinis and Ureaplasma (Bitsch et al. 1976). Further, strains of $M$. bovigenitalium are isolated now and then (Friis, unpublished).

The most commonly isolated species is $M$. dispar, which in an examination (Bitsch et al.) of 50 pneumonic calf lungs from 46 herds was recovered from 31 lungs ( $62 \%)$. Many of the strains could not be identified as $M$. dispar by the disc growth inhibition test till after filtration and cloning. This, together with the recovery in other cases of strains with the cultural characteristics of M. dispar, but displaying complete resistance in initial serologic screening, left the impression that some heterogeneity might exist within this species of bovine mycoplasma. It was therefore found relevant to examine a number of isolates tentatively identified as M. dispar more closely with regard to their relation to the type strain of the species.

The results of the comparison are given in the present paper. 


\section{MATERIAL AND METHODS}

Strains of M. dispar

Seventy strains were examined, all recovered from pneumonic tissue of calf lungs received at the Laboratory for routine diagnostic purposes. 'Thirty-one originated from the above-mentioned project. The rest were collected at random, from among isolates showing the typical cultural characteristics of M. dispar: fairly slow growth, strong acidification, centreless colonies on solid medium. All the strains were filtered through a $0.45 \mu \mathrm{m}$ membrane and subsequently cloned twice on solid medium.

\section{Serologic examination}

Using hyperimmune rabbit antiserum for the type strain of M. dispar, NCTC 10125, all the strains were tested by the ordinary disc growth inhibition test (DGI), the metabolism inhibition test (MI) (Friis 1971) and the indirect epi-immunofluorescence test (IMF) (Rosendal \& Black 1972). In the DGI test the plates were incubated at $37 \mathrm{C}$ in atmospheric air for $24 \mathrm{hrs}$. followed by three days in air $+5-10 \% \mathrm{CO}_{2}$. In the MI test 100 color-changing units were used. The IMF test was modified, in that the washing procedures were reduced to dropwise application of PBS onto the agar blocks for a few minutes instead of submerging the blocks in a bath. By this modification floating-away of colonies was largely avoided. In the IMF test, just one dilution (1:100) of antiserum was used.

'Three strains (Md15, Md26, Md70) which, by DGI, were found resistant to the antiserum for the type strain of $M$. dispar were cloned a third time and used for production of rabbit hyperimmune antisera. Hereafter the four strains were each tested against all four antisera by the methods described above.

\section{RESULTS}

The testing results for the 70 strains are shown in Table 1. It appears that 67 strains reacted positively with antiserum for the type strain in all of the three tests employed. Three strains, however, viz. Md15, Md26, and Md70, did not react in DGI, but did so in either MI or IMF.

Comparison of the group of three variant strains to the type strain of M. dispar by DGI cross testing is shown in Table 2. It appears that, although there was just a weak inhibition of Strain 
Ta ble 1. Identification of 70 strains of $M$. dispar by means of rabbit hyperimmune antiserum for the type strain NCTC 10125.

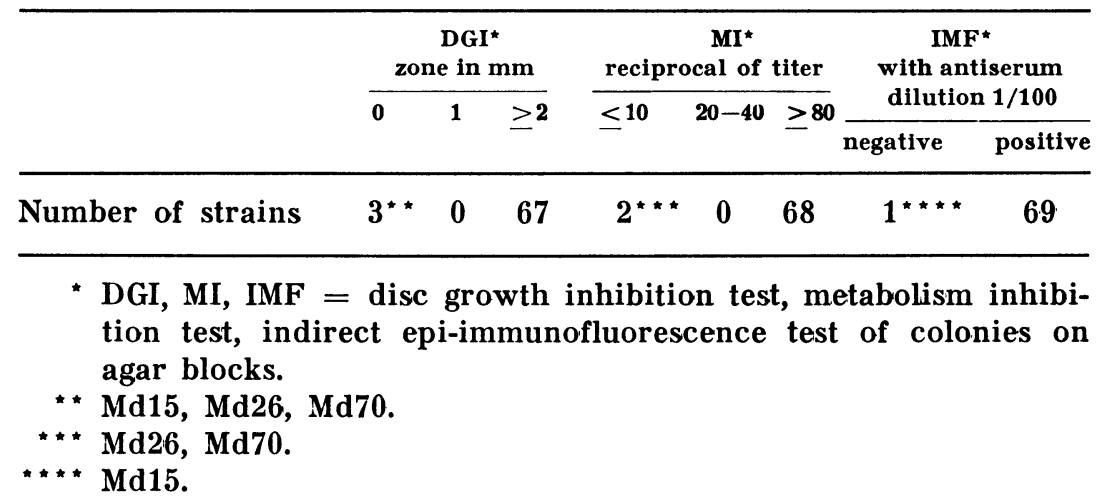

Md70 by Antiserum Md26, all of the three strains were inhibited distinctly by antiserum for each of the two others as well as by homologous antiserum, and that they were all resistant to antiserum for the type strain. Except for a very weak inhibition by Antiserum Md26 the type strain did not react to antiserum for any of the three strains.

In MI (Table 3) all three variant strains were inhibited significantly by antiserum for each of these strains, except that Strain Md70 was but weakly inhibited by Antiserum Md26. Strain Md15 was strongly inhibited by antiserum for the type strain, whereas the other two variant strains were largely unaffected by this antiserum. Strain Md15 was found remarkably sensitive in this test.

T a b l e 2. Variant strains of M. dispar compared to the type strain by the disc growth inhibition test.

\begin{tabular}{lcccc}
\hline & \multicolumn{4}{c}{ Antiserum } \\
\cline { 2 - 5 } Antigen & type strain $^{\star}$ & Md15 & Md26 & Md70 \\
\hline Type strain & 4 t, $5 r^{\star *}$ & 0 & $1 \mathrm{r}$ & 0 \\
Md15 & 0 & 6 nt, $7 r$ & $2 n t, 4 r$ & $4 n t, 6 r$ \\
Md26 & 0 & $5 t, 6 r$ & $3 t, 5 r$ & $4 t, 5 r$ \\
Md70 & 0 & $3 t, 5 r$ & $2 r$ & $4 t, 6 r$ \\
\hline
\end{tabular}

* NCTC 10125.

** $t$, nt, $r=$ zones in $m m$ of, resp., total, near total and relative inhibition of colonies around the disc. 
T a b l e 3. Variant strains of M. dispar compared to the type strain by the metabolism inhibition test.

\begin{tabular}{lrrrc}
\hline & \multicolumn{4}{c}{ Antiserum } \\
\cline { 2 - 5 } Antigen & type strain $^{\star}$ & Md15 & Md26 & Md70 \\
\hline Type strain & 640 & $<10$ & 10 & variable $^{\star \star}$ \\
Md15 & 1280 & 10240 & 640 & 640 \\
Md26 & $<10$ & 160 & 320 & 160 \\
Md70 & 20 & 160 & 20 & 160 \\
\hline
\end{tabular}

* NCTC 10125.

* * Titers from 10 to 80 observed.

Figures indicate reciprocals of titers.

In IMF, except for the failure of Strain Md15 to react with antiserum for the type strain, all four strains reacted with each of the four antisera in dilution 1/100. Even when using dilutions $1 / 50$ and $1 / 25$, the type strain antiserum did not react with Strain Md15 (Table 4).

T a b l e 4. Variant strains of M. dispar compared to the type strain by indirect epi-immunofluorescence test on colonies on agar.

\begin{tabular}{lcccc}
\hline & \multicolumn{4}{c}{ Antiserum } \\
\cline { 2 - 5 } Antigen & type strain & Md15 & Md26 & Md70 \\
\hline Type strain $^{\star \star}$ & + & + & + & + \\
Md15 & $0^{\star \star \star}$ & + & + & + \\
Md26 & + & + & + & + \\
Md70 & + & + & + & + \\
\hline
\end{tabular}

* In dilution 1/100.

** NCTC 10125.

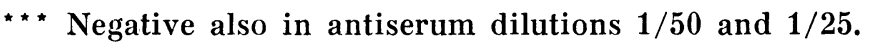

\section{DISCUSSION}

Of the 70 isolates examined, 67 could be identified as regular members of the species $M$. dispar. The three remaining isolates were completely resistant to antiserum for the type strain of M. dispar in DGI, but could be identified as M. dispar by either MI or IMF.

By DGI cross testing (Table 2) the three strains were found to constitute a serologically homogeneous group distinct from the type strain of M. dispar. Also by MI (Table 3) a high degree 
of relatedness between the three strains was revealed, but the homogeneity was not complete, as is evidenced by the negligible inhibition of Strain Md70 by Antiserum Md26. Though also by MI the group was found clearly separate from the type strain, incontestable signs of relatedness were present, as proved mainly by the strong inhibition of Strain Md15 by antiserum for the type strain, but also by the moderate inhibition of the type strain by Antiserum Md70. The relatedness of the three strains to the type strain of M. dispar was further corroborated by IMF (Table 4) which showed complete cross reaction between all four strains and the corresponding antisera (diluted 1/100) except in the testing of Strain Md15 against type strain antiserum.

Isolates of M. dispar showing unreactivity when tested by DGI against type strain antiserum have been reported on earlier by Gourlay \& Leach (1970) who were unable to identify 13 out of 36 strains examined. That work was followed up by cross-testing of 12 strains, including the type strain, NCTC 10125 (462/2), by MI and indirect hemagglutination test, and it was found that all 12 strains formed a serologically homogeneous group (Howard et al. 1974).

From the work reported in this paper it appears that the three variant strains form a distinct serogroup partially separate from the type strain of $M$. dispar. The cross reactions shown by IMF clearly underline its relatedness to $M$. dispar and hardly allow its being regarded as a subspecies. It therefore seems reasonable to conclude that Danish isolates of bovine mycoplasmas which display the cultural characteristics of $M$. dispar constitute a serologic entity, though with some heterogeneity.

\section{REFERENCES}

Bitsch, V., N. F. Friis \& H. V. Krogh: A microbiological study of pneumonic calf lungs. Acta vet. scand. 1976, 17, 32-42.

Friis, N. F.: Mycoplasmas cultivated from the respiratory tract of Danish pigs. Acta vet. scand. 1971, 12, 69-79.

Gourlay, R. N.\&R. H. Leach: A new mycoplasma species isolated from pneumonic lungs of calves (Mycoplasma dispar sp. nov.). J. med. Microbiol. 1970, 3, 111-123.

Howard, C. J., R. N. Gourlay \& Jacqueline Collins: Serological comparison and haemagglutinating activity of Mycoplasma dispar. J. Hyg. (Lond.) 1974, 73, 457-466.

Rosendal, S. \& F. T. Black: Direct and indirect immunofluorescence of unfixed and fixed mycoplasma colonies. Acta path. microbiol. scand. Section B 1972, 80, 615-622. 


\section{SAMMENDRAG \\ Heterogenitet indenfor arten Mycoplasma dispar.}

Ialt 70 kvægmykoplasmastammer, som alle var isoleret fra tilfælde af kalvepneumonier, og som udviste de for M. dispar typiske kulturelle egenskaber, blev unders $\varnothing$ gt serologisk for tilhørsforhold til denne species ved hjælp af disk-væksthæmningsmetoden, stofskiftehæmningsmetoden og den indirekte epi-immunofluorescensmetode udf $\varnothing \mathrm{rt}$ på kolonier pả agar. Det fandtes, at 67 stammer kunne regelret identificeres som M. dispar. De resterende 3 stammer fandtes at udgøre en homogen serogruppe, som delvis adskilte sig fra typestammen af $M$. dispar. Den påviste forskel synes dog for ringe til at berettige særskilt gruppering af de 3 stammer $i$ en ny subspecies.

Det må derfor konkluderes, at danske stammer af M. dispar udg $\varnothing \mathbf{r}$ en serologisk helhed, omend en vis heterogenitet er til stede.

(Received February 20, 1978).

Reprints may be requested from: N. F. Friis, The State Veterinary Serum Laboratory, Bülowsvej 27, DK-1870 Copenhagen V, Denmark. 